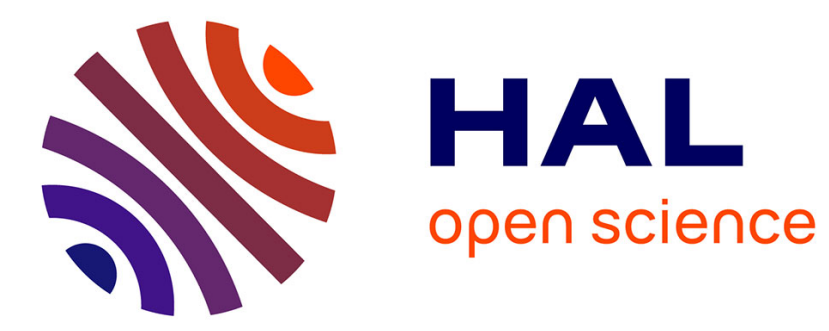

\title{
Interactions entre virus chez un hôte commun. I. Interférences négatives, antagonisme, prémunition, résistance induite
}

Georges Marchoux

\section{- To cite this version:}

Georges Marchoux. Interactions entre virus chez un hôte commun. I. Interférences négatives, antagonisme, prémunition, résistance induite. Agronomie, 1987, 7 (3), pp.149-162. 10.1051/agro:19870301 . hal-02728821

\section{HAL Id: hal-02728821 \\ https://hal.inrae.fr/hal-02728821}

Submitted on 2 Jun 2020

HAL is a multi-disciplinary open access archive for the deposit and dissemination of scientific research documents, whether they are published or not. The documents may come from teaching and research institutions in France or abroad, or from public or private research centers.
L'archive ouverte pluridisciplinaire HAL, est destinée au dépôt et à la diffusion de documents scientifiques de niveau recherche, publiés ou non, émanant des établissements d'enseignement et de recherche français ou étrangers, des laboratoires publics ou privés. 


\title{
Interactions entre virus chez un hôte commun I. - Interférences négatives, antagonisme, pré- munition, résistance induite
}

\author{
Georges MARCHOUX
}

I.N.R.A., Station de Pathologie végétale, Centre de Recherches d'Avignon - F 84140 Montfavet

\begin{abstract}
L'interférence entre virus est généralement la conséquence de l'inoculation séquentielle d'une plante par un virus inducteur puis par un virus challenger.

L'effet de l'interaction sur le virus challenger peut s'exprimer au moins de quatre manières : diminution du nombre de lésions locales, réduction de leur taille, diminution de la concentration en virions et prévention (ou retard) des symptômes.

On pense donc que le virus inducteur peut agir au niveau de l'initiation de l'infection, ou plus tard au cours de la réplication et de la pathogenèse du virus challenger.

Les différentes théories qui ont été avancées pour expliquer ces phénomènes ont été réunies dans cet article. Au plan pratique, la prémunition (protection par une souche faible) a permis de protéger certaines cultures. La résistance induite et notamment les substances qui lui sont liées (protéines et facteurs anti-viraux) font l'objet actuellement d'un important effort de recherche.

Les progrès rapides de la biologie moléculaire offrent de nouvelles possibilités d'investigation et d'exploitation des phénomènes d'interactions virales. Les techniques de génie génétique permettent d'envisager l'intégration dans le génome des plantes, des ADN complémentaires ou anti-sens de parties de génome viral, satellite ou viroïde impliqués dans les phénomènes de protection contre les virus et les viroïdes.
\end{abstract}

Mots clés additionnels : Effet plages vertes, satellite, hypersensibilité, facteur anti-viral, protéine b, interféron.

Interactions between viruses in plants. I. Negative interference, antagonism, premunition, induced resistance.

In general, interference between viruses follows sequential inoculation of an inducer virus and a challenger virus. There are four types of limitation in the infective cycle of the challenger virus : decrease in the number of lesions ; decrease in the size of the lesions ; decrease in virus concentration ; prevention (or delay) of symptoms. Negative interference between viruses can take place during initiation of infection or later, during multiplication and pathogenesis of the challenger virus. The principles underlying the phenomena are not understood and various theories have been proposed and are here reviewed. The use of mild strains (premunition) is one example of virus-induced protection of plants against virus diseases. Two other types of virus-induced protection (acquired systemic resistance and the production of anti-viral factors) are under intensive research for possible application in disease control. Recent developments in the molecular biology of viruses indicate opportunities from investigating virus-induced protection at the molecular level and hence for employing genetic engineering techniques to facilitate virus and viroid control.

Additional key words : Cross protection, green island effect, satellite, hypersensitivity, antiviral factor $(A V F)$, pathogenesis-related proteins.

\section{INTRODUCTION}

Dans la nature il arrive souvent, notamment chez les plantes à multiplication végétative, qu'une plante ou un organe soit infecté par deux ou plusieurs virus. La co-infection peut entraîner des interactions positives, indifférentes ou négatives (KASSANIS, 1963).

L'étude de ces dernières est généralement placée dans la seule perspective de la lutte contre les virus alors que le problème des interactions entre virus dans son ensemble offre des aspects théoriques très intéressants notamment pour une meilleure compréhension des principales phases du cycle viral. Par là même, elles posent aussi des questions auxquelles il est difficile de répondre avec les connaissances actuelles.

Nous aborderons d'abord, les interférences négati- 
ves ou antagonistes entre deux virus. Elles sont très intéressantes pour l'étude des réactions de défense de la plante en réponse à l'infection virale.

L'interaction antagoniste est généralement une conséquence de l'inoculation ou de l'infection séquentielle par deux virus*. Le premier est appelé virus inducteur, protecteur ou prémunisant. Le second est le virus challenger ou virus d'épreuve.

Selon le lieu d'inoculation du virus challenger, on distingue deux grands groupes d'interactions antagonistes. Dans le premier, le virus challenger est appliqué à des plantes, à des feuilles déjà envahies par le virus protecteur. Il s'agit notamment de la protection croisée ou prémunition, observée principalement lorsque virus inducteur et challenger sont des souches d'un même virus.

Le second groupe correspond à la situation de résistance induite ou immunité acquise rencontrée lorsque le virus d'épreuve est appliqué sur des organes non contaminés par le virus inducteur qui généralement produit une réaction d'hypersensibilité (lésions nécrotiques) et reste localisé dans les organes inoculés.

Autrement dit, avec la résistance induite et contrairement à la prémunition, la présence de la souche protectrice n'est pas nécessaire dans les tissus à protéger.

Il est certain qu'à côté de ces deux situations les plus connues, existe tout un gradient d'interactions entre virus car elles sont probablement un phénomène plus général qu'exceptionnel. En effet, la primo-infection virale altère toujours la physiologie, l'activité métabolique, l'anatomie de la plante. L'bôte infecté devient donc différent de la plante saine et il serait surprenant qu'ils réagissent de la même manière à une inoculation challenger.

Selon le niveau de l'inhibition exercée sur le virus challenger, on a longtemps distingué l'immunité quand il ne peut s'installer et se multiplier et l'interférence quand il est capable de se multiplier même faiblement. Nous reviendrons sur cette distinction discutable qui dépend pour une grande part de la sensibilité des méthodes de détection mises en œuvre.

L'interférence entre virus a, généralement été mise en évidence et mesurée par la modification des réactions produites par le virus challenger chez l'hôte préinfecté par le virus inducteur. Schématiquement, la réaction des plantes vis-à-vis des virus correspond à deux situations : sensibilité et résistance. Lorsque la plante est sensible et (ou) que la souche est virulente, elle développe des symptômes plus ou moins généralisés et plus ou moins intenses selon l'agressivité du virus. La plante résistante par hypersensibilité, réagit en formant des lésions locales nécrotiques et le virus reste localisé dans l'organe inoculé.

A partir de ces cas simplistes, on peut envisager quatre types d'interactions selon la réaction des plantes à la première et à la seconde inoculation.

\begin{tabular}{ccl}
\hline Situation & Première inoculation & Seconde inoculation \\
\hline A & sensibilité & $\begin{array}{l}\text { sensibilité } \\
\text { hypersensibilité }\end{array}$ \\
B & hypersensibilité & $\begin{array}{l}\text { sensibilité } \\
\text { hypersensibilité }\end{array}$ \\
\hline C & & \\
\hline
\end{tabular}

* Virus : ensemble comprenant souches ou isolats d'un même virus sauf quand la précision est apportée.
D'autre part, il faut considérer si virus inducteur et challenger sont des souches d'un même virus, des virus apparentés ou des virus non apparentés.

\section{GRANDS GROUPES D'INTERACTIONS ENTRE VIRUS}

\section{A. L'hôte est sensible aux virus inducteur et challenger}

\section{Virus différents}

Fréquemment le virus challenger s'installe, se multiplie et induit des symptômes comparables chez la plante pré-infectée et la plante saine.

Dans un certain nombre de cas, en revanche, la première infection a pour conséquence de diminuer ou ralentir la multiplication et les symptômes produits par le virus challenger. L'inhibition n'est pas forcément plus accusée entre virus apparentés que non apparentés et elle n'est pas toujours réciproque. De plus l'antagonisme ne s'exprime pas avec toutes les souches des deux partenaires.

De façon générale, l'inhibition exprimée par la diminution de la concentration du virus challenger est d'autant plus forte que l'intervalle entre l'inoculation des virus inducteur et challenger augmente.

On peut penser que le virus challenger se réplique plus lentement dans les cellules pré-infectées ou qu'il infecte moins de cellules chez les plantes déjà envahies par un premier virus.

Les exemples d'antagonisme entre deux virus sont très rares. Le phénomène n'a été décrit qu'entre deux potyvirus (KASSANIS, 1963) et népovirus (FULTON, 1975 ; JONES, 1976). Dans les deux cas, l'antagonisme est unilatéral.

Un cas d'interférence négative entre un virus (CTV)* et un viroïde (CEV) a été signalé chez le Citrus (CHEEMA et al., 1983).

\section{Souches d'un même virus et viroüdes}

La prémunition entre souches d'un virus a été mise en évidence il y a plus d'un demi-siècle (Mc KINNEY, 1929). L'inoculation primaire avec une souche du TMV provoquait sur Tabac des symptômes assez sévères, puis les jeunes feuilles formées après l'infection étaient d'apparence saine. Une seconde inoculation même avec une souche plus pathogène du même virus n'entraînait aucun symptôme et la seconde souche ne se multipliait pas. La plante infectée est donc protégée contre la surinfection. Aussi définit-on la prémunition comme l'état de protection que confère à la plante une première souche (protectrice - inductrice - prémunisante) contre l'infection par une seconde souche (challenger ou d'épreuve).

Les mécanismes de la prémunition entre souches de virus sont peu connus. On sait que la plante est prémunie, si la souche protectrice est toujours présente dans la plante au moment de la surinfection. Si la plante est placée temporairement dans des conditions défavorables, la souche protectrice ne se multiplie pas dans les jeunes feuilles et la souche challenger inoculée en conditions favorables pourra produire des symptômes comparables à ceux induits chez une plante saine.

* Voir abréviations en annexe. 
La prémunition se démontre plus facilement, au niveau des symptômes en utilisant une souche protectrice peu ou pas pathogène et une souche challenger plus agressive. Le phénomène peut être réciproque c'est-à-dire que la protection est également mise en évidence si la souche challenger est utilisée comme souche protectrice. Pour le démontrer, il faut dans ce cas réaliser des rétro-inoculations de contrôle ou étudier la multiplication des souches.

$\mathrm{Si}$ le phénomène est réciproque on peut parler de protection croisée, " cross protection 》 des anglophones. En fait ces derniers l'utilisent à notre avis de façon abusive pour toutes les situations d'interférence entre souches notamment dans les cas où la protection n'a été mise en évidence que dans un seul sens (FULTON, 1975).

La protection croisée est un phénomène très spécifique qui a, souvent dans le passé, été utilisée pour démontrer la parenté entre virus inducteur et virus challenger. Pour ce dernier il est avantageux de choisir une souche qui donne des lésions locales. Ce qui nous replace dans le cas $B$ ci-après.

Le phénomène de protection croisée et (ou) de prémunition a été mis en évidence chez des hôtes divers et avec la plupart des groupes de phytovirus y compris chez les virus à ADN comme les caulimovirus (TOMLINSON \& SHEPHERD, 1978), et les viroïdes (NIBLETT et al., 1979).

La prémunition s'observe entre souches apparentées d'un même virus. Elles peuvent appartenir, ou non, à un même groupe sérologique. L'important est que la souche prémunisante soit adaptée, c'est-à-dire se multiplie activement chez l'hôte (MARROU \& MIGLIORI, 1971). La prémunition peut ne pas être réciproque (LIMA \& NELSON, 1975 ; FulTON, 1978).

La protection mesurée par la gravité des symptômes induits par la souche challenger peut être totale ou plus ou moins partielle. Lorsque la protection est totale, la mise en évidence de la souche challenger n'est plus possible pendant toute la durée d'observation des plantes. Cependant, dans certains cas, l'absence de symptômes typiques de la souche challenger n'implique pas qu'elle soit totalement incapable de se multiplier dans la plante prémunie. Dans les cas de protection partielle, seulement un certain pourcentage de plantes ne présenteront pas les symptômes de la souche challenger et se révèleront prémunies.

\section{Interaction entre souches et (ou) entre satellites}

La présence d'un satellite a souvent pour conséquence de ralentir la multiplication du virus assistant mais en plus, deux satellites différents d'un même virus peuvent entrer en compétition pour leur multiplication par le virus assistant (KASSANIS \& WHITE, 1972).

Chez le CMV, plusieurs types d'ARN-5 ou satellites ont été mis en évidence à côté des trois ARN génomiques et de l'ARN-4 subgénomique. Chez plusieurs hôtes sensibles au CMV, la présence de l'ARN-5 dans l'inoculum entraîne l'atténuation des symptômes liée à une réduction de la concentration virale (KAPER \& TOUSSIGNANT, 1977). Chez la tomate alors que les $A R N-5$ de type $D$ induisent une nécrose létale, les ARN-5 de type $R$ entraînent un symptôme de mosaïque et filiformisme très atténué. Or la contamination de jeunes plantes par une souche contenant l'ARN-5 de type $\mathrm{R}$ les protège vis-à-vis d'une infection ultérieure par un isolat inducteur de nécrose. Cette protection serait liée à des mécanismes d'interférences entre les deux types d'ARN satellites (JACQUEMOND, 1982).

\section{B. L'hôte est sensible au virus inducteur et hyper- sensible au virus challenger}

\section{Virus différents}

Lorsqu'un virus qui produit des lésions locales est inoculé sur des feuilles déjà infectées par un virus systémique, le nombre de lésions obtenues est réduit par rapport à celui obtenu avec la même préparation sur des plantes saines.

Les exemples sont relativement nombreux où ce type d'interférence est observé avec des virus non apparentés. Ainsi les CMV, PVY, TEV, virus qui se généralisent chez le Tabac "Xanthi nc " réduisent d'environ $50 \mathrm{p} .100$ le nombre de lésions locales produites par une inoculation ultérieure du TMV (KASSANIS et al., 1974). Le taux de réduction varie avec le virus inducteur et avec l'intervalle ménagé entre l'inoculation du virus inducteur et celle du " challenger ". Il faut que le virus inducteur soit établi de manière systémique dans les feuilles avant l'inoculation du virus challenger. L'effet inhibiteur est maximal au cours de la multiplication active du virus inducteur et décroît ensuite.

Les phénomènes d'interférence entre virus non apparentés sont souvent limités à certaines souches des virus inducteur et challenger.

Dans un certain nombre de cas, c'est la taille des lésions locales induites par le virus challenger qui est diminuée. Un bon exemple de ce type d'interférence est la réduction d'environ $30-50$ p. 100 de la taille des lésions locales induites par le TMV sur des feuilles de Tabac « Samsun NN » infectées par le PVY. La réduction de la taille augmente avec le temps à partir de trois jours après l'inoculation du PVY. La croissance des lésions locales chez les plantes pré-infectées apparaît plus lente et s'arrête plus tôt que chez les plantes saines.

Notons, cependant, qu'ici la réduction de taille des lésions locales est moins importante que dans le cas de la résistance systémique induite par une inoculation préalable du TMV sur les feuilles de la base (cas C ciaprès) Ross, $1961 b$ ).

\section{Souches d'un même virus}

Dès 1934, KUNKEL montra que des Nicotiana sylvestris Spezg \& Comes systémiquement infectés par lè TMV, ne développaient plus de lésions lorsqu'ils recevaient une souche proche (Mosaïque aucuba) induisant normalement la formation de lésions locales. L'inhibition de la formation de lésions est totale lorsque les souches sont inoculés à deux jours d'intervalle. L'inhibition peut être partielle et le dénombrement des lésions locales permet de l'estimer.

Comme nous l'avons dit précédemment, ce type de réaction facile à observer a été utilisé comme moyen d'établir une parenté entre virus inducteur et virus challenger. La portée de cette technique est très limitée et elle ne peut représenter qu'une méthode d'appoint. D'autre part, il peut $y$ avqir absence de protection par 
la première souche vis-à-vis de la souche challenger pourtant très proche en sérologie.

Soulignons le fait que si la souche challenger est très concentrée, elle produit quelques lésions qui apparaissent dans les zones vert-foncé et non dans les zones vert-clair de la mosaïque induite par la souche protectrice (FULTON, 1951). Les aires vert-foncé renferment moins de virus que les zones claires. Ce résultat a été confirmé avec d'autres virus (REID \& MATTHEWS, 1966 ; ATKINSON \& MATTHEWS, 1970 ; LOEBENSTEIN et al., 1977).

Nous reviendrons sur ce phénomène à propos des hypothèses sur les mécanismes de prémunition.

\section{L'hôte est hypersensible aux virus inducteur et challenger}

Chez le Tabac à réaction hypersensible, le virus ne diffuse pas à partir des lésions nécrotiques vers les zones saines : la réaction d'hypersensibilité protège la plante, elle correspond à une défense. Cette notion de réaction de défense liée à l'hypersensibilité a été renforcée par la découverte d'une résistance induite.

L'inoculation du TMV à Nicotiana tabaccum var. "Xanthi » porteur du gène NN produit des lésions nécrotiques sur les feuilles inoculées. L'inoculation, plusieurs jours plus tard, des demi-feuilles opposées et des feuilles supérieures provoque l'apparition de taches nécrotiques de plus petite taille ou (et) moins nombreuses que sur les feuilles correspondantes de tabacs sains. L'effet inhibiteur est maximum de 7 à 10 jours après l'inoculation du virus inducteur et se prolonge plusieurs semaines (YARWOOD, 1960 ; ROSS, $1961 a, b$ ).

L'effet protecteur du TMV n'est pas spécifique de ce virus, cependant il est plus grand quand il s'exerce visà-vis d'une souche challenger de TMV.

Chez un hôte donné, les capacités inductrices de résistance ne sont pas non plus spécifiques et d'autres virus hypersensibilisants ont induit chez le Tabac une résistance acquise systémique vis-à-vis d'eux-mêmes ou d'autres virus. Ainsi le phénomène de résistance induite après une réaction d'hypersensibilité a été observé avec des virus variés chez différentes plantes (LOEBENSTEIN, 1972 ; RoSS, 1974) appartenant aux familles des Solanées, Légumineuses, Cucurbitacées (JENNS et al., 1979), Amaranthacées, Caryophyllacées. C'est d'ailleurs chez l'Oeillet que le phénomène avait été entrevu la première fois (GILPATRICK \& WEINTRAUB, 1952).

Nous reviendrons sur la signification biologique de la réduction du nombre de lésions locales, d'une part, et la diminution de leur taille d'autre part. On sait que les deux inhibitions ne sont pas toujours corrélées et la taille des lésions locales serait une valeur moins variable donc plus performante dans l'étude de la résistance induite (ROBERTS, 1983).

\section{L'hôte est hypersensible au virus inducteur et sen- sible au virus challenger}

A notre connaissance un seul exemple de cette situation a été décrit. L'inoculation des feuilles de la base du Concombre var. "Marketer » avec le TNV (mais aussi un champignon ou une bactérie) induit une résis- tance systémique vis-à-vis du CMV qui normalement se généralise. Cette résistance s'exprime par une diminution du nombre des taches chlorotiques primaires sur les feuilles inoculées et un retard dans le développement de la mosaïque systémique par rapport aux plantes saines. La résistance s'exprime même si le CMV est transmis par les pucerons (BERGSTROM et al., 1982).

\section{E. Discussion}

Les résultats de l'interaction entre deux virus sont généralement appréciés par les effets observés sur le déroulement de l'infection par le virus challenger. $\mathrm{Si}$ celui-ci produit des lésions locales, les effets notés porteront essentiellement sur la taille, le nombre, voire l'absence de celles-ci.

Il est généralement admis que la réduction du nombre de lésions locales correspondrait à une inhibition de l'établissement de l'infection. Cet effet est obtenu tant avec un virus inducteur systémique dans des organes infectés (cas B - protection croisée entre souches) qu'avec un virus inducteur hypersensibilisant dans des organes non contaminés (cas $\mathrm{C}$ - résistance induite non spécifique).

Soulignons, toutefois, que le niveau de l'inhibition est bien supérieur dans le cas de la prémunition.

La réduction de la taille des lésions locales est interprétée comme le résultat d'une inhibition de la multiplication virale. Elle s'observe dans les cas de prémunition entre souches et de résistance induite non spécifique. Chez cette dernière la diminution du nombre de lésions locales ne serait qu'un effet secondaire. En effet, l'examen aux ultra-violets des feuilles protégées révèle des taches fluorescentes aussi nombreuses que les lésions locales bien développées sur les feuilles témoins (ROSS, 1974).

Si le virus challenger devient systémique, les effets de l'interaction avec le virus protecteur sont susceptibles de porter sur l'installation (réussite de l'infection diminuée), la multiplication (intensité et vitesse de la synthèse des virions), la migration de cellule à cellule et le transport à plus longue distance (vitesse de généralisation de la maladie) et enfin sur la pathogenèse (vitesse et intensité des symptômes). De telles inhibitions sont révélées séparément ou en association chez les plantes prémunies par une souche d'un même virus. Elles ont été exceptionnellement observées entre virus différents mais appartenant au même groupe (cas A).

Le cas $D$, correspondant à l'induction de la résistance vis-à-vis d'un virus systémique, est unique à notre connaissance.

Il apparaît ainsi que les deux principales situations d'interférence entre virus inoculés successivement sont : la prémunition, phénomène spécifique de niveau élevé, et la résistance induite ou résistance acquise systémique non spécifique, mais de niveau plus faible.

De nombreux travaux qui ne sont pas spécifiques à la virologie, sont consacrés à l'étude de la résistance induite que la plante met en place à la suite d'une première réaction d'hypersensibilité (KUC, 1981). Nous ne retiendrons que les aspects principaux correspondant à l'interférence entre virus. D'autre part, nous ne les séparerons pas complètement de ceux de la prémunition car toutes les deux rendent compte d'un même phénomène : une première infection virale entraîne 
chez la plante des changements qui augmentent les capacités de résistance à une attaque ultérieure.

\section{HYPOTHĖSES SUR LES MÉCANISMES D'INTERACTION ENTRE VIRUS}

De nombreuses hypothèses ont été proposées pour expliquer les réactions de défense de la plante mise en place à la suite d'une première infection virale (HAMILTON, 1980).

Certaines hypothèses anciennes sont actuellement controversées car elles s'appuyaient par exemple sur la non-multiplication de la souche challenger alors que les techniques de détection modernes révèlent sa présence chez les plantes prémunies. D'autres reposaient sur des concepts de base qu'il faut maintenant abandonner. Ainsi les concepts selon lesquels, l'infection d'une cellule ne peut être réalisée que par une seule particule ou, si deux populations de particules virales sont mises en présence, l'une exclut l'autre dans le processus de l'infection (SIEGEL, 1959). Autrement dit, une cellule déjà infectée par une souche d'un virus ne pourrait plus l'être par une seconde.

La technique de culture des cellules végétales isolées a permis de lever une certaine ambiguité. Les protoplastes sont évidemment un matériel intéressant pour étudier, dans un système synchrone, les interactions entre virus appliqués simultanément ou de façon séquentielle. La culture des protoplastes préparés à partir des tissus infectés « in situ » a également permis de préciser la situation. D'autant qu'un progrès parallèle était enregistré dans les méthodes de détection et d'analyses biochimiques des virus (DAWSON et al., 1975 ; BARKER \& HARRISON, 1978; OTSUKI \& TAKEBE, 1978).

A la lumière de ces nouvelles acquisitions, quelles sont les hypothèses qui sont encore avancées ? Nous reprendrons les quatre phases du cycle déjà discutées au paragraphe précédent, quoique bien conscients que fixation et décapsidation sont des phénomènes encore peu connus. En revanche, les connaissances sur la traduction, la réplication et l'encapsidation ont beaucoup progressé ces dernières années.

\section{A. Interactions des virus pour l'installation}

\section{Occupation des récepteurs cellulaires par la souche protectrice}

Se fondant sur les faits que chez une plante prémunie, les symptômes de la souche challenger n'apparaissent pas et que cette souche ne peut être ré-isolée, les premiers auteurs ont conclu à la non-multiplication de cette souche d'épreuve (THUNG, 1931). Par analogie avec les phénomènes d'interférence au niveau de la pénétration chez les virus animaux, plusieurs auteurs ont pensé que l'infection de la cellule végétale par la souche protectrice aboutissait à la saturation, à l'altération, à la destruction des sites ou récepteurs cellulaires nécessaires à l'installation et la multiplication de la souche d'épreuve. Afin de rendre compte de la spécificité de la prémunition, les sites réceptifs seraient relativement spécifiques d'un virus ou même d'un groupe particulier de souches.
Logiquement, seul un effet inhibiteur spécifique, exercé par la même souche non infectieuse (ou la protéine-capside) ou par des souches reliées (ou leur protéine), peut être interprété comme le reflet de l'interaction virus-récepteur. En effet, chez le Chenopodium amaranticolor (Coste \& Reyn) il y a interférence entre certains virus (TMV ou BSMV) et leurs capsides homologues. La capside a donc un effet inhibiteur vis-à-vis de son virus homologue mais pas vis-à-vis du virus hétérologue. Ces résultats vont dans le sens de l'existence de récepteurs différents, spécifiques de chaque virus (NOVIKOV \& ATABEKOV, 1970). En revanche, il n'y a pas interférence entre l'ARN du TMV et le virus entier. Les cellules qui deviennent résistantes au virus entier demeurent sensibles à l'ARN infectieux (ATABEKOV et al., 1970).

Il est probable que la protéine capsidique empêche, au moins partiellement, la capacité de reconnaissance entre le virus entier et les récepteurs cellulaires spécifiques. Il y aurait saturation de ces récepteurs par les protéines-capside et les particules virales ne pourraient participer à l'infection. La spécificité de l'interférence entre les virus des plantes et les capsides homologues pourrait être la conséquence de la spécificité d'interaction entre les particules virales et les récepteurs.

Le phénomène de compétition, entre virus reliés pour les récepteurs cellulaires (interférence sur l'attachement du virus), offre donc une approche expérimentale à l'évaluation des récepteurs dans la cellule.

Nous ne connaissons pas la nature des structures appelées récepteurs cellulaires ou sites d'infection. Le phénomène $d$ 'interférence suggère que l'interaction entre les composants structuraux de la capside virale et les récepteurs cellulaires est une phase nécessaire dans la réplication des virus végétaux. Elle peut être le facteur qui contrôle la gamme d'hôtes aux stades précoces de l'interaction virus-cellule.

\section{Hypothèse de la non-décapsidation de la souche challenger}

Nous avons vu ( $\S$ II B) que $N$. sylvestris infecté par une souche de TMV qui induit une mosaïque peut être surinfecté, au niveau des tissus verts mais pas sur les zones vert pâle, par une souche de TMV à lésions locales.

Or, le rapport entre le nombre de lésions locales obtenues sur les feuilles mosaïquées et sur les feuilles saines est plus élevé avec l'ARN qu'avec le virus intact. De plus l'ARN surinfectant est capable, lui, de produire des lésions locales aussi bien dans les zones claires que dans les zones foncées de la mosaïque. Ce résultat a été vérifié chez $N$. longiflora (Cav) et Capsicum baccatum L. D'autre part, l'ARN de la souche de TMV à lésions locales encapsidé dans la protéine manteau du BMV (virus éloigné) conserve la faculté de surinfection. En revanche celle-ci est perdue si l'ARN est protégé par la capside d'une souche de TMV. L'adjonction de bentonite qui favorise la décapsidation restaure la faculté-de surinfection.

Il apparaît ainsi que la prémunition observée au niveau des zones vert-clair pourrait être le résultat de la non-décapsidation des virions de la souche challenger (SHERWOOD \& FULTON, 1982). Des résultats récents obtenus avec le CMV vont dans le sens de cette hypothèse (DoDDS et al., 1985). 


\section{B. Interaction pour la multiplication}

Un certain nombre d'expériences d'interaction entre virus pathogènes ou non, montrent que les phénomènes d'antagonismes peuvent survenir aussi après la phase d'installation du virus challenger (WU \& RAPPAPORT, 1961 ; OTSUKI \& TAKEBE, 1978).

On sait que souche prémunisante et souche challenger du TMV peuvent être présentes ensemble dans certains protoplastes issus de mésophylle prélevé chez une plante "prémunie » et surinfectée (CASSELS \& HERRICK, 1977).

Lors de l'inoculation simultanée de deux souches de TMV à des protoplastes sains de tabac, on met en évidence une infection double dans 80 p. 100 des cellules. Dans ce cas, plus de 90 p. 100 des particules virales contiennent des antigènes des deux souches (mélange phénotypique). Même si on pratique des inoculations séquentielles il peut y avoir 50 p. 100 de protoplastes doublement infectés. Ces résultats infirment l'hypothèse selon laquelle deux souches différentes ne pourraient infecter la même cellule (SIEGEL, 1959).

Le fait que les 2 souches peuvent infecter un même protoplaste n'implique pas que l'infection par une souche n'est pas affectée par l'autre. Au contraire, les 2 souches entrent en compétition durant la réplication et certains protoplastes infectés par la première souche deviennent réfractaires à l'infection par la souche challenger. Cette résistance à l'inoculation de la souche d'épreuve augmente dans les premières heures avec l'intervalle de temps écoulé depuis l'inoculation de la souche protectrice (OTSUKI \& TAKËBE, 1978).

Un phénomène comparable a été mis en évidence dans les protoplastes de Nicotiana benthamiana (Domin) qui deviennent réfractaires à la souche challenger du RRSV à partir de 6 à $12 \mathrm{~h}$ après l'inoculation de la souche protectrice du même virus (BARKER \&\& HARRISON, 1978).

A noter que la résistance des protoplastes préinfectés par le TMV s'exprime également vis-à-vis du CMV. Cependant, le temps nécessaire pour la mise en place de cette résistance est plus long. Il apparaît ainsi que la réaction de défense est plus spécifique pour un virus apparenté que pour un virus non apparenté (OTSUKI \& TAKEBE, 1978).

Quels sont les mécanismes qui peuvent être envisagés pour tenter d'expliquer l'inhibition de la multiplication du virus challenger?

\section{Compétition au niveau cellulaire}

\section{a) Compétition pour la traduction des $A R N$}

L'initiation de la traduction est un stade critique pour l'établissement de l'infection virale dont les mécanismes ne sont pas encore complètement éclaircis pour les cellules végétales et animales.

Il faut considérer l'ARN viral comme un compétiteur des ARN messagers de l'hôte. On peut également envisager que les ARN de souches ou de virus différents mis en présence, entreront en compétition pour les ribosomes et que ceux-ci peuvent avoir une affinité meilleure pour les sites d'initiation de l'ARN prémunisant.

La traduction « in vitro » des ARN viraux dans les systèmes acellulaires a permis de faire des progrès considérables. On sait que les $\mathrm{ARN}$ des virus à génome divisé ont des efficjences de traductions différentes. Ainsi les $\mathrm{ARN}_{4}$ (messager de la capside) du BMV et de l'AMV sont préférentiellement traduits au détriment des $\mathrm{ARN}_{1}$ ou $\mathrm{ARN}_{2}$ homologues ou hétérologues (SHIH \& KAESBERG, 1976 ; VAN TOL \& VAN VLOTENDOTING, 1979). D'autre part, l'ARN-4 du BMV empêche la traduction de l'ARN-3 comme le font aussi l'ARN-4 du CCMV et le satellite du TNV. En revanche, l'ARN-4 de l'AMV n'empêche pas la traduction simultanée de l'ARN-3 du BMV (DAVIS \& KAESBERG, 1974 ; HERSON et al., 1979).

Plus récemment avec un virus à génome simple, les ARN de 2 souches de TMV apportées ensemble au début de l'expérience sont traduites simultanément. Au contraire la traduction de l'ARN de la souche apportée en second est inhibée quand la traduction de la première est commencée. Les facteurs d'initiation seraient des facteurs limitants dans une cellule. Ils seraient également spécifiques puisque la traduction de l'ARN de l'AMV n'est pas inhibée par une traduction commencée avec l'ARN du TMV et inversement (SALOMON \& BAR JOSEPH, 1982). Ce résultat indiquerait que l'ARN de l'AMV utilise une classe de ribosomes ou des facteurs d'initiation différents de ceux du TMV.

\section{b) Compétition pour les réplicases}

Le rôle des sites d'accrochement des réplicases a été envisagé pour comprendre la prémunition. On sait que ces sites ont des localisations différentes selon les groupes de virus : protéines chloroplastiques pour les tymovirus (HATTA \& MATTHEWS, 1976), mitochondriales (Tobravirus, HARRISON et al., 1970), tonoplasmiques (Cucumovirus, HONDA et al., 1974) et nucléaires (Rhabdovirus, Wolanski \& CHAMBERS, 1971). Dans ce cas, on comprendrait que les sites dans une cellule soient en nombre limité pour deux souches d'un même virus et non pour des virus différents et éloignés. On peut également envisager que les sites de réplication deviennent moins accessibles pour l'ARN challenger dans les cellules pré-inoculées ou induites à résister (DE ZOETEN et al., 1972 et $\S$ III A-1).

Le désavantage compétitif de l'ARN challenger pourrait résulter de la compétition au niveau des complexes de réplication.

Ainsi, la réplicase spécifique de la souche protectrice pourrait ne pas transcrire, mais au contraire, séquestrer l'ARN challenger et donc empêcher sa réplication. Les liaisons ARN-enzymes s'établiraient en raison du fait que cette réplicase serait très proche mais non identique à la réplicase spécifique de la souche challenger. Ce type de liaisons ne pourrait s'établir qu'entre réplicases et ARN de virus apparentés. Il faut cependant souligner qu'avec les virus à génorne divisé, la réplicase codée par un pseudorecombinant viable entre deux virus apparentés est active vis-à-vis de chacune des molécules d'ARN provenant de l'un ou l'autre virus parent. C'est notamment le cas chez les Tobravirus (SANGER, 1968 ; ROBINSON, 1977), Nepovirus (HARRISON et al., 1974 ; RANDLES et al., 1977), et les Cucumovirus (HABILI \& FRANCKI, 1974 ; MARCHOUX et al., 1975).

D'autre part, des protoplastes du mésophylle de tabac peuvent être doublement infectés par le BMV et le CCMV, deux bromovirus apparentés. Le BMV domine dans les infections mixtes; les 2 types de particules sont pourtant produits mais seules celles du 
BMV sont infectieuses. Les particules défectives du CCMV ne renferment que l'ARN-3, la réplication partielle du génome du CCMV est indiquée aussi par le fait que l'ARN-2 ne peut être détecté dans les protoplastes doublement infectés.

Les protéines codées par l'ARN-3 sont en revanche produites dans les cas d'infection mixte. Il est envisagé que le BMV puisse exploiter les produits des gènes du CCMV dont les particules infectieuses ne peuvent être synthétisées (SAKAI et al., 1983).

A noter, dans ces expériences, qu'aucun phénomène de masquage génotypique n'a pu être mis en évidence bien que celui-ci ait été observé « in vitro », probablement en raison d'une localisation différente dans des systèmes membranaires de la cellule (BURGESS et al., 1974).

On peut imaginer que dans les situations de prémunition, la réplicase de la souche inductrice puisse utiliser les ARN $(+)$ de la souche challenger très proche mais la synthèse d'ARN(-) serait trop faible pour produire une quantité suffisante d'ARN $(+)$ permettant à la souche challenger de se multiplier dans la plante prémunie (Ross, 1974). Plus simplement, l'ARN challenger pourrait utiliser la réplicase synthétisée par la souche protectrice mais cet ARN serait, au départ, en net désavantage compétitif avec l'ARN de la souche prémunisante déjà bien installée (FLETCHER \& ROWE, 1975 ; BARKER \& HARRISON, 1978). Le même raisonnement a été avancé pour expliquer l'interférence entre ARN satellites (JACQUEMOND, 1982).

\section{c) Mécanismes de régulations}

Dans certains tissus infectés, la réplication du virus est relativement ralentie. Après transfert de protoplastes dans un milieu de culture, la réplication reprend. Ce résultat indique que les cellules infectées peuvent être dans un état réprimé qui inhibera la réplication du virus challenger (FOGLEIN et al., 1975).

\section{* Régulation exercée par les protéines}

La protéine capsidique pourrait jouer un rôle à ce niveau comme cela a été montré dans le cas de l'autorégulation de la multiplication de certains bactériophages à ARN (ROBERTSON et al., 1968). Ce mécanisme qui fait intervenir la nature de la capside expliquerait pourquoi la prémunition s'observe plus souvent entre souches apparentées notamment au niveau sérologique.

Mais l'infection virale se traduit par la synthèse de plusieurs protéines autres que la protéine capsidique. Il n'est pas exclu que, en dehors de la réplicase, certaines aient un rôle dans la régulation de la réplication de l'ARN viral (KIHO \& NISHIGUCHI, 1984).

Les polypeptides autres que la capside synthétisés dans les plantes infectées par le CMV pourraient modifier la spécificité des ribosomes en faveur de l'ARN viral (ZIEMIECKI \& WOOD, 1976). L'ARN messager de la souche protectrice occuperait en premier les ribosomes, qui ne seraient plus disponibles pour l'ARN challenger. Le rôle des protéines b sera discuté en D. 2 .

\section{* Transencapsidation}

Dans une cellule déjà infectée par le virus inducteur $A$ il y a des particules virales $[A]^{A}$. Lors de l'inoculation avec le virus challenger $B$ il pourrait se former des particules $[\mathrm{B}]^{\mathrm{A}}$ constituées de l'ARN-B encapsidé dans la protéine manteau de A présente en grande quantité. Ce phénomène de transencapsidation unilatérale a été mis en évidence avec des virus non apparentés de morphologie différente (DODDS \& HAMILTON, 1976). Plusieurs auteurs ont émis l'hypothèse que ce phénomène serait à la base de la prémunition entre souches. L'hypothèse est séduisante car on peut imaginer que le masquage génotypique survienne davantage entre virus apparentés du fait d'une plus grande facilité d'assemblage protéine - ARN quand les composants structuraux appartiennent à des virus plus proches.

De plus, on sait qu'il y a prémunition pour la souche challenger du TMV apportée sous forme d'ARN tant qu'il y a multiplication active de la première souche. Il a donc été suggéré que l'ARN challenger pourrait être encapsidé par les sous-unités protéiques qui se trouvent en grande quantité à ce moment (DE ZOETEN \& FULTON, 1975).

Encapsidé dans la protéine manteau hétérologue, l'ARN de la souche challenger séquestré ne pourrait se répliquer et les tests courants, notamment en sérologie, ne permettraient plus de détecter ce virus. Certains résultats vont à l'encontre de cette théorie. Ainsi, le mutant PM1 du TMV qui produit une protéine capside insoluble, exerce cependant un effet protecteur vis-àvis d'une souche commune. Le mutant Ni 118 qui produit une sous-unité protéique dénaturée non fonctionnelle à $35^{\circ} \mathrm{C}$, incapable d'encapsider son propre ARN, exerce également un effet protecteur vis-à-vis de la souche commune (ZAITLIN, 1976). Inversement le mutant Ni 2519 qui, lui, produit une protéine fonctionnelle, mais dont l'assemblage est déficient à $35^{\circ} \mathrm{C}$, n'exerce pas d'effet protecteur (JOCKUSCH, 1968).

Il apparaît donc que si le masquage génotypique peut, dans certains cas, rendre compte du phénomène de prémunition, il n'a probablement pas une portée générale, et notamment pas pour les viroïdes (NIBLETT et al., 1979). En revanche l'exemple de protection complète entre virus différents, présenté au paragraphe II A, susciterait peut-être l'exploration de cette hypothèse.

\section{* Régulation exercée par des $A R N$}

Des données récentes indiquent que la régulation de la transcription et de la traduction sont associées à des protéines mais également à des acides nucléiques complémentaires des ARN messagers. Ces « mic ARN 》= messager interfering complementary, contrôleraient l'expression de certains gènes au niveau de la traduction en formant peut-être des «hybrides » avec les ARN messagers (TRAVERS, 1984). On peut imaginer que les « mic ARN » liés à la première infection exerceraient un effet inhibiteur sur la traduction de la souche challenger.

D'autre part, les ARN polymérases - ARN dépendantes dont l'activité augmente après l'infection pourraient avoir un rôle dans les mécanismes de régulation. Elles induisent « in vitro » la synthèse d'ARN bicaténaires qui seraient impliqués dans les mécanismes de résistance de type interféron (D. 2.).

\section{* Concentration en formes réplicatives}

L'inhibition de la synthèse virale semble dans certains cas liée à une accumulation de la forme bicaténaire. On observe, en effet, avec le CMV une corrélation négative entre la quantité d'ARN-5 bicaténaire et 
la teneur en virus assistant. L'ARN-5 bicaténaire est presque toujours détecté en grande quantité dans les zones de tissus sans symptômes (vert-foncé) chez le Tabac. L'abondance de la forme réplicative de l'ARN satellite « encombrerait » la réplicase du virus assistant (HABILI \& KAPER, 1981). L'accumulation d'ARN bicaténaire chez le tabac infecté par un mutant avirulent du TMV, va dans le même sens (CHANG et al., 1982).

\section{Compétition au niveau de la plante}

Du fait de cette compétition et de ces régulations, le cycle du virus challenger est soit très lent soit peu productif. En effet la prémunition se traduit fréquemment par une diminution de la concentration en virions atteinte par la souche challenger. Ainsi le rendement en virions de la souche commune du TMV obtenu chez des plantes pré-infectées par les mutants PM1 (ZAITLIN, 1976) ou Ni 118 (JOCKUSCH, 1968) est réduit de 65 à 80 p. 100 par rapport aux témoins.

Des travaux récents utilisant de nouvelles techniques de détection ont permis d'aborder l'étude de la multiplication de la souche challenger.

En 1977, CASSELS et HERRICK démontrent, dans des essais où les tomates sont inoculées artificiellement avec deux souches de TMV :

- que la plante prémunie héberge les deux souches prémunisante et challenger en l'absence de tout symptôme propre à la souche forte ;

- que la souche challenger se multiplie plus faiblement dans les plantes prémunies que dans les plantes saines ;

- qu'il y a un équilibre au niveau de la multiplication et (ou) de la migration des 2 souches. Cet équilibre est modifié par la concentration des inoculums, la surface et les organes inoculés, l'état physiologique des plantes, les conditions de milieu...;

- que la rupture de prémunition (symptômes de la souche forte) intervient lorsque le rapport (souche challenger/souche prémunisante) devient supérieur à 10 .

Les ruptures du phénomène de protection pourraient donc s'expliquer par une vitesse de multiplication et/ou de migration de la souche challenger bien plus grande que celle de la souche prémunisante (FLETCHER \& RowE, 1975).

Dans les essais de prémunition des tomates en serre, les ruptures de prémunition ne peuvent s'expliquer par un surcroît de multiplication de la souche challenger mais plutôt par un ralentissement de multiplication de la souche faible ou la manifestation d'une souche nouvelle sous l'effet d'une modification des facteurs abiotiques. Le rôle important joué par la valeur du rapport souche challenger/souche protectrice a été confirmé par plusieurs auteurs mais celui-ci varie en fonction des souches utilisées et des conditions d'expériences (BURGYAN \& GABORJANYI, 1984). Ces auteurs soulignent, d'autre part, l'importance de la proportion des particules à mélange phénotypique.

L'étude de l'interférence entre deux souches de CMV appartenant à des groupes sérologiques et biologiques différents a été abordée chez le tabac. Les chances d'installation de la souche challenger dépendent essentiellement de la concentration de la souche protec- trice préexistante dans les tissus surinfectés. Dans un grand nombre de cas les souches qui se multiplient lentement sont progressivement remplacées par la souche challenger qui, au contraire, se multiplie plus activement. Mais qu'il y ait prémunition ou non, on ne détecte généralement plus qu'une seule souche dans les tissus infectés de façon systémique. Les souches thermosensibles (MARCHOUX et al., 1976) qui ne prémunissent que partiellement à $22^{\circ} \mathrm{C}$, ne protègent plus à $32{ }^{\circ} \mathrm{C}$ vis-à-vis des souches thermorésistantes (DEVERGNE \& CARDIN, 1979 ; DOUINE et al., 1979).

En se plaçant à la température optimale, DODDS (1982) a obtenu des résultats comparables avec des souches, ayant des différences de vitesse de migration électrophorétique.

Pour etre premunisante une souche doit donc se maintenir à un niveau de concentration suffisant dans l'ensemble des tissus de la plante à protéger. Elle doit donc être bien adaptée à cet hôte. Si la prémunition n'est pas complète, c'est probablement parce que la vitesse de multiplication et de migration de la souche protectrice devient trop lente. Ces propriétés sont à déterminisme génétique. Symétriquement, la capacité d'une souche d'épreuve de surmonter la prémunition est fonction de sa vitesse de multiplication également contrôlée par son génome.

Chez les virus à génome divisé, l'étude des propriétés des pseudorecombinants obtenus par réassociation des ARN génomiques de deux souches a permis de localiser sur un des ARN l'aptitude à surmonter la prémunition. Chez le RRSV et le TSV elle est liée, pour l'essentiel, à l'ARN du composant lourd (HARRISON \& HANADA, 1976 ; FULTON, 1978). Chez le TBRV, au contraire, ce serait sur l'ARN le plus petit (DOZ et al., 1982).

Chez le CMV, les différences de comportement des souches et les phénomènes de prémunition liés à la présence d'ARN satellites ne paraissent s'expliquer qu'en fonction de différences génétiques très faibles. L'établissement de la séquence complète (334 à 336 nucléotides) de plusieurs ARN-5 (\# 100000 d) a permis de révéler une vingtaine de substitutions et quelques délétions et insertions qu'il reste à interpréter (RICHARDS et al., 1978).

Une situation similaire a été observée chez les virödes où des cas de protection existent entre deux souches du PSTV qui diffèrent seulement par 4 ou 5 bases sur les 359 nucléotides constitutifs de la molécule (NiBlett et al., 1979).

\section{Compétition pour l'expression du pouvoir patho- gène}

Le rôle primordial de la vitesse de multiplication de la souche protectrice n'est probablement pas un cas général. Ainsi, le niveau de protection croisée entre souches de TSV n'est pas relié à la concentration de la souche protectrice dans les tissus (FULTON, 1978). Les dosages sérologiques (méthode ELISA) en fonction du temps montrent que les antigènes des souches prémunisante et challenger se trouvent à la même concentration chez la plante prémunie et la plante témoin. Les deux souches se multiplient apparemment indépendamment l'une de l'autre.

Des résultats comparables ont été mis en évidence 
avec les souches de plusieurs Népovirus notamment le TBRV (DOZ et al., 1982). Si la souche prémunisante et la souche d'épreuve se multiplient en apparence indépendamment l'une de l'autre, au même taux que chez les plantes témoins inoculées séparément par l'une ou l'autre souche, il faut envisager l'hypothèse que la protection reposerait sur la compétition des deux souches pour les voies métaboliques aboutissant à l'expression des symptômes.

\section{Intervention de substances inhibitrices}

Les théories précédentes font appel soit à une interaction directe entre virus inducteur et challenger soit à une compétition pour les structures cellulaires. Nous envisagerons maintenant une intervention de médiateurs chimiques.

\section{Cas de la prémunition}

Chez le tabac infecté par le CMV, le pouvoir infectieux révélé dans les plages vertes est moins de 5 p. 100 de celui des plages jaunes et seulement 2 à 7 p. 100 des protoplastes provenant des plages vertes renferment du virus. Pourtant les zones vertes sont résistantes à la surinfection par 3 souches de CMV (pas vis-à-vis du TMV).

Il apparaît donc que les cellules des plages vertes sont peu aptes à la multiplication du CMV que ce soit en première ou seconde inoculation. La prémunition serait donc associée à des cellules qui n'assurent déjà qu'une faible multiplication de la souche protectrice (LOEBENSTEIN et al., 1977).

Comme nous l'avons dit précédemment, de nombreuses cellules de tissus de tabac ou tomate pourtant prémunis, peuvent être exemptes de la souche protectrice de TMV. Il semble donc qu'un mécanisme initial de protection empêche la multiplication de la souche protectrice elle-même, dans certaines cellules. On a émis l'hypothèse que des substances inductrices diffusant à partir des cellules infectées vers les cellules non infectées rendraient celles-ci résistantes (ATKINSON \& MATTHEWS, 1970 ; Shalla \& PETERSEN, 1978).

Des extraits préparés à partir de plantes infectées et ajoutés à un inoculum viral ont révélé une activité inhibitrice de l'infection (CHADHA \& Mc NEILL, 1969 ; JANICKA-CZARNECKA \& NIENHAUS, 1981).

De plus, la moitié des plantes régénérées par culture " in vitro » des zones vertes, citées précédemment, se révèlent sans virus et sont résistantes à l'infection durant plus de deux mois. Un extrait de ces plantes montre une activité inhibitrice de l'infection (MURAKISHI \& CARLSON, 1976). Cependant comme les extraits inhibiteurs étudiés jusqu'ici agissent sur des virus différents, ils ne permettent pas d'expliquer la spécificité étroite de la prémunition.

\section{Résistance induite après réaction d'hypersensibilité}

La résistance induite est un phénomène très complexe simplement abordé ici sous l'angle d'un phénomène qui peut contribuer à la compréhension des mécanismes mis en jeu lors des expériences d'interférences entre souches et virus.

Dans ce type de résistance, le virus inducteur n'est pas présent dans les tissus protégés, c'est donc tout naturellement que des inducteurs et des substances inhibitrices induites après une première inoculation et susceptibles de diffuser des cellules infectées vers les organes sains ont été recherchées. Des inhibiteurs de nature protéique ( Interfering substance » ; LOEBENSTEIN \& ROSS, 1963) ou phosphoglycoprotéique (Antiviral facteur «AVF », SELA \& APPLEBAUM, 1962 ; KATO \& MISAWA, 1976 ; MOZES et al., 1978 : SCHUSTER \& WERTZLER, 1982) ont été mis en évidence chez les tabacs porteurs du gène $\mathrm{N}$. Un inhibiteur de la réplication a également été mis en évidence dans les cultures de protoplastes des tabacs NN (LOEBENSTEIN \& GERA, 1981 ; GERA \& LOEBENSTEIN, 1983). L'AVF injecté dans le pétiole inhibe la multiplication du TMV dans les tissus foliaires (ANTIGNUS et al., 1977). Un précurseur de l'AVF serait présent dans toutes les espèces de Nicotiana puisqu'un traitement, avec une préparation enzymatique brute provenant de Nicotiana glutinosa (gène d'hypersensibilité $\mathrm{N}$ ), active le pré-AVF chez le tabac sensible (gène n) (SELA et al., 1978). L'activité antivirale de l'AVF s'exprime au niveau picomole et n'est pas spécifique. Elle résulterait de l'altération de l'activité ATP-polymérase qui entraîne la synthèse d'analogues de nucléotides inhibiteurs de la translation et de la réplication des virus dans les cellules végétales (SELA, 1981 ; REICHMAN et al., 1983).

Ces différentes propriétés ont fait rapprocher l'AVF de l'interféron du règne animal, synthétisé rapidement par la cellule en réponse à une infection virale. Les poly I et poly $C$ induisent la synthèse d'AVF suggérant l'intervention d'ARN bicaténaire pour cette induction (GAD-EDELBAUM et al., 1983).

D'autres auteurs ont montré que la résistance induite chez le tabac hypersensible était liée à la synthèse de protéines $b$ (la capside étant a) qui sont absentes dans la plante saine, jeune et dans de bonnes conditions de croissance (GIANINAZZI et al., 1969). Les résultats ont été étendus à d'autres couples virus-hôtes hypersensibles (VAN LOON, 1976). Ces protéines, au nombre de 11, chez Nicotiana ont été partiellement caractérisées (GianinAzZI et al., 1977 ; ANTONIW \& PIERPOINT, 1978 ; AHL et al., 1985 ; JANET-FRITIG, 1986).

Le phénomène semble plus général puisque bactéries, champignons, substances et « stress » divers peuvent être à l'origine d'une résistance acquise vis-à-vis d'un virus chez ses hôtes hypersensibles (MANDRYCK, 1963 ; HETCH \& BATEMAN, 1964 ; JENNS et al., 1979). Dans certains de ces cas la synthèse de protéines b a été mise en évidence (GIANINAZZI et al., 1980 ; BONNET et al., 1986). Inversement les virus hypersensibilisants peuvent induire une résistance à d'autres agents pathogènes (champignons-bactéries) (JENNS \& KUC, 1980 ; Mc INTYRE et al., 1981 ; KUC, 1981 ; GIANINAZZI, 1983).

A l'heure actuelle le rôle des protéines b dans le système de défense induit chez l'hôte par un virus est équivoque (FRASER \& CLAY, 1983 ; VAN LOON, 1983). Toutes les tentatives pour montrer un effet inhibiteur direct ont échoué. De plus, elles ont été trouvées chez des plantes infectées de façon systémique (KASSANIS $\boldsymbol{e} t$ al., 1974 ; FRASER, 1979) ou ayant atteint le stade de la floraison. Elles sont synthétisées dans des plantes qui demeurent sensibles ou chez d'autres plantes seulement après le développement de la résistance induite (FRA SER, 1982). Des cas de sensibilisation après synthèse 
des protéines b ont même été mis en évidence (FRASER et al., 1979).

Là aussi le rapprochement entre protéines b et interféron a été fait. L'effet d'inducteurs d'interféron a donc été essayé chez les plantes. L'acide polyacrylique injecté dans les feuilles de tabac entraîne une diminution de la taille et du nombre des lésions locales produites par le TMV. La résistance induite s'accompagne de la synthèse de protéines b comparables à celles décrites précédemment (GIANINAZZI \& KASSANIS, 1974). Beaucoup de points restent cependant à préciser avant de parler d'interféron végétal. Le principal défaut des protéines b est leur faible mobilité (KASSANIS, 1983 ; CHESSIN, 1983). Or un composé mobile, transporté dans les vaisseaux serait présent chez les Nicotiana et serait responsable de la synthèse des protéines b (AHL et al., 1983).

\section{APPLICATIONS PRATIQUES}

Dès 1933, SALAMAN suggérait de mettre à profit le phénomène de prémunition entre souches d'un même virus pour lutter contre certaines maladies virales.

C'est ainsi que beaucoup plus tard les tomates ont été protégées du TMV qui est transmis par contact et affecte très sévèrement la production sous serre. En inoculant aux jeunes plants un mutant artificiel très peu virulent du TMV on a effectivement obtenu une protection contre la surinfection par les souches agressives naturelles (RAST, 1972-75; MARROU \& MIGLIORI, 1972 ; CHANNON et al., 1978).

La technique a été utilisée dans plusieurs pays d'Europe, en Amérique, en Nouvelle-Zélande et au Japon. En France durant plus de 10 ans, 100 millions de plants prémunis ont été produits. Ils ont été protégés efficacement des infections par le TMV dans plus de 90 p. 100 des cas assurant ainsi une production satisfaisante des tomates jusqu'à l'arrivée de variétés résistantes (NAVATEL et al., 1983).

La réussite de cette méthode de protection est sous la dépendance de facteurs biotiques et abiotiques en partie incontrôlables et quelques accidents ont été constatés en France comme à l'étranger. Outre les mécanismes envisagés en III. B.2, les ruptures de prémunition peuvent s'expliquer par la multiplication active d'un mutant pathogène présent en quantité infime dans l'inoculum ou apparu par mutation sous l'effet de facteurs particuliers affectant la physiologie des plantes.

Par ailleurs et malgré les craintes, l'infection massive des plantes par la souche prémunisante n'a pas conduit, sauf dans un cas (HoLLING, 1978) à l'extension de nouveaux mutants plus virulents. Cependant, un nouvel équilibre des populations naturelles a été enregistré dans les pépinières pratiquant la prémunition (FLETCHER \& BUTLER, 1975).

Le TMV étant transmis de façon externe par la graine, on a envisagé de prémunir les tomates dès ce stade. Le faible taux de transmission de la souche prémunisante ne l'a pas permis (RAST, 1979).

La prémunition a également trouvé une application chez une plante pérenne pour lutter contre le virus de la Tristeza des Citrus (Clostérovirus transmis par différents pucerons selon le mode semi-persistant). Les souches prémunisantes ont été isolées d'arbres ne présentant pas de symptômes et poussant dans des planta- tions dépérissantes. Les souches n'ont ultérieurement subi aucune sélection ou purification supplémentaire, elles résultent donc d'un équilibre naturel qui paraît être un garant de la stabilité de la protection. Au Brésil, huit millions d'orangers «Pera » et plusieurs millions de citronnier «Galego » ont été prémunis.

En 1985, le chiffre total atteindrait plus de 30 millions d'arbres. De plus, il serait possible de multiplier les variétés prémunies en prélevant des greffons sur ces plants prémunis (COSTA \& MULLER, 1980). En Australie des pamplemoussiers inoculés il y a plus de 20 ans avec une souche faible sont encore protégés (Cox et al., 1976). En Israël des manques de protection ont été liés à l'âge avancé des arbres, dans ces conditions la multiplication des souches agressives n'est pas complètement supprimée et elles sont ensuite disséminées par les pucerons (BAR-JOSEPH, 1978).

De nombreux laboratoires étudient les possibilités d'utilisation de la prémunition pour protéger les plantes contre les virus et viroïdes d'importance économique quand il n'y a pas d'autres solutions (génétiques notamment). Citons parmi les plus récents travaux effectuées sur les plantes cultivées :

Viroïde PSTV chez la Tomate (NIBLETT et al., 1979), viroïdes CSV et ChCMV chez le Chrysanthème (NIBLETT et al., 1979), CMV (et ARN satellites) chez la Tomate (JACQUEMOND, 1982 ; DODDS et al., 1982-85), TMV chez le Piment (GoTo et al., 1984). PRSV chez le Melon (YEH \& GoNSALVES, 1984), TAV chez la Tomate (KUTI \& MOLINE, 1986).

\section{CONCLUSION}

Parmi les phénomènes d'interférence négative entre souches de virus, la prémunition est le plus intéressant car il aboutit à un niveau de protection des plantes suffisant pour être utilisé dans la pratique. De nombreuses hypothèses ont été avancées pour expliquer ce phénomène spécifique ; elles font intervenir une compétition des souches prémunisante et challenger pour des phases essentielles de l'installation et de la réplication.

D'autres mécanismes faisant intervenir plus généralement l'interaction du génôme viral et celui de la plante sont probablement mis en jeu. Ainsi, dans certains cas, l'aptitude prémunisante d'une souche semble davantage s'exprimer sur la régulation de l'expression des symptômes de la souche challenger. Enfin, plusieurs résultats tendent à montrer l'induction, par la première infection, de substances inhibitrices.

La résistance induite à la suite d'une première réaction d'hypersensibilité n'est spécifique ni d'un virus ni limitée à ceux-ci, aussi a-t-elle fait l'objet de nombreux travaux en phytopathologie. Un effort particulièrement important a été consacré à la mise en évidence de substances liées à la pathogenèse qui induiraient une résistance selon des mécanismes similaires à ceux de l'interféron.

Prémunition, résistance induite, antagonisme entre virus, dépendent de facteurs extrêmement complexes où concourent tous les éléments spécifiques ou non de la plante. Il est donc vraisemblable que les phénomènes d'interaction, entre virus et entre souche de virus (viroïdes et satellites), obéissent non pas à un seul mécanisme mais à plusieurs, qui seuls ou associés peuvent se traduire par l'apparition de phénomène d'anta- 
gonisme. Les résultats obtenus dans un système donné sont donc à généraliser avec prudence. Il apparaît de plus en plus probable que la prémunition repose sur l'interaction des génômes du virus et de l'hôte. L'exemple des viroïdes et des ARN satellites montre que le phénomène peut mettre en jeu des différences d'informations génétiques très réduites (quelques bases) (NIBLETT et al., 1979 ; RICHARDS et al., 1978).

Les expériences d'inoculation simultanée ou séquentielle de deux virus ou deux souches sont, d'autre part, intéressantes pour mieux comprendre les mécanismes mis en jeu lors des différentes phases du cycle viral et notamment préciser leur localisation dans la cellule.

Au plan pratique, nous avons vu que la protection efficace des plantes par prémunition exige que la souche faible protectrice qui doit être réinoculée à chaque culture, se multiplie activement et se généralise dans la plante. Une généralisation stable conditionne également la bonne transmission du " caractère prémuni » à la descendance chez les plantes à multiplication végétative. Pour dépasser ces contraintes et limites de la méthode actuelle, plusieurs laboratoires envisagent d'introduire et de propager dans les plantes-hôtes, tout ou partie du génôme viral impliquée dans la prémunition $(\S$ III B1)*, une souche faible de viroïde ( $§$ II A 2), un satellite interférant avec la multiplication virale ( $\$$ II A 1 et III B 1). Les nouvelles possibilités de transfert des copies de ces ARN sous forme d'ADNc par des plasmides bactériens utilisés comme vecteurs de transfert et d'intégration font que ces projets apparaissent aujourd'hui réalisables. De plus, on sait que l'ADNc du viroïde PSTV est capable de déclencher le processus infectieux et permet la production de molécules d'ARN identiques à l'ARN natif (CRESS et al., 1983).

L'autre voie de recherche s'appuie sur l'existence des ARN anti-messagers ( mic ARN ») qui par la formation probable d'hybrides ARN-ARN, peuvent contrôler l'expression de certains gènes ( $\S$ III $1 \mathrm{C}$ ). On peut envisager de produire à partir de fraction de génôme viral une copie ADN anti-sens pouvant être transcrite en « mic ARN ». Ensuite, le transfert et l'intégration de l'ADN anti-sens dans le génôme de la plante pourront être réalisés à l'aide des vecteurs précédents.

Rappelons cependant que les mécanismes mis en jeu dans les deux cas sont très spécifiques. L'éventuelle application de transfert de gènes viraux à la protection des plantes ne pourrait que concerner des maladies d'importance économique indiscutable.

On peut enfin envisager le transfert des gènes responsables des mécanismes de défense d'une plante qui les possède à une plante qui en est dépourvue. La réaction d'hypersensibilité produite par une première infection spécifique devrait conférer à cette plante une résis-

\footnotetext{
* L'intérêt de cette stratégie a été vérifié récemment. Des tabacs ont été protégés des attaques par le TMV grâce à l'insertion du gènecapside du virus dans leur ADN (PowelL-ABEL et al., 1986). La portée pratique du résultat reste cependant à démontrer car la protection n'est que partielle et temporaire.
}

tance acquise systémique. Cette protection aurait l'avantage de ne pas être spécifique, mais nous avons vu que le niveau de résistance est généralement insuffisant dans la pratique.

Malgré ces restrictions dictées par le réalisme agronomique, il est probable que l'exploitation par génie génétique des situations d'interactions négatives entre virus ouvrira une voie nouvelle dans la recherche des méthodes de lutte contre les virus végétaux.

Reçu le 19 décembre 1985. Accepté le 4 décembre 1986.

\section{ABRÉVIATIONS UTILISÉES}

$\begin{array}{ll}\text { AMV } & \text { Alfalfa mosaic virus } \\ \text { BMV } & \text { Brome mosaic virus } \\ \text { BSMV } & \text { Barley stripe mosaic virus } \\ \text { CCMV } & \text { Cowpea chlorotic mottle virus } \\ \text { CEV } & \text { Citrus exocortis viroid } \\ \text { ChCMV } & \text { Chrysanthemum chlorotic mottle viroid } \\ \text { CMV } & \text { Cucumber mosaic virus } \\ \text { CSV } & \text { Chrysanthemum stunt viroid } \\ \text { CTV } & \text { Citrus tristeza virus } \\ \text { PRSV } & \text { Papaya ringspot virus } \\ \text { PSTV } & \text { Potato spindle tuber viroid } \\ \text { PVX } & \text { Potato virus X } \\ \text { PVY } & \text { Potato virus Y } \\ \text { RRSV } & \text { Raspberry ringspot virus } \\ \text { TAV } & \text { Tomato aspermy virus } \\ \text { TBRV } & \text { Tomato black ring virus } \\ \text { TEV } & \text { Tobacco etch virus } \\ \text { TMV } & \text { Tobacco (ou Tomato) mosaic virus } \\ \text { TmRSV } & \text { Tomato ringspot virus } \\ \text { TRSV } & \text { Tobacco ringspot virus } \\ \text { TSV } & \text { Tobacco streak virus }\end{array}$

Bromovirus $=$ Virus sphériques à ARN transmis par coléoptères

Caulimovirus $=$ Virus sphérique à ADN transmis par pucerons de manière semi-persistante

Clostérovirus $=$ Virus flexueux à ARN transmis par pucerons sous le mode semi-persistant

Cucumovirus $=$ Virus sphériques à ARN transmis par pucerons sous le mode non persistant

Lutéovirus $=$ Virus sphériques à ARN transmis par pucerons sous le mode persistant

Népovirus $=$ Virus sphériques à ARN transmis par nématodes

Potyvirus $=$ Virus flexueux à ARN transmis par pucerons sous le mode non persistant

Rhabdovirus $=$ Virus bacilliformes à ARN, certains transmis par pucerons

Tobravirus = Virus en bâtonnet à ARN transmis par nématodes 
Abel P. P., Nelson R. S., Barun de, Hoffmann N., Rogers S. G., Fraley R. T., Beachy R. N., 1986. Delay of disease development in transgenic plants that express the tobacco mosaic virus coat protein gene. Science, 232, 738-743.

Ahl P., Gianinazzi S., Cornu A., 1983. A new potential for enhancing resistance to tobacco mosaic virus in Nicotiana species. Neth. J. Plant Pathol., 89, 319-320.

Ahl P., Antoniw J. F., White R. F., Gianinazzi S., 1985. Biochemical and serological characterization of b-proteins from Nicotiana species. Plant Molecular Biology, 4, 31-37.

Antoniw J. F., Pierpoint W. S., 1978. The purification and properties of one of the $4 \mathrm{~b}$ » proteins from virus-infected tobacco plants. J. Gen. Virol., 39, 343-350.

Antignus Y., Sela I., Harpaz I., 1977. Further studies on the biology of an antiviral factor (AVF) from virus-infected plants and its association with the N-gene of Nicotiana species. J. Gen. Virol., 35, 107-116.

Atabekov J. G., Novikov V. K., Vishnichenko V. K., Javakhia V. G., 1970. A study of the mechanism controlling the host range of plant viruses. II. - The host range of hybrid viruses reconstituted in vitro and of free viral RNA. Virology, 41, 108-115.

Atkinson P. H., Matthews R. E. F., 1970. On the origin of dark green tissue in tobacco leaves infected with tobacco mosaic virus. Virology, 40, 344-356.

Bar-Joseph M., 1978. Cross-protection incompleteness : a possible cause for natural spread of citrus tristeza virus after a prolonged lag period in Israel. Phytopathology, 68, 1110-1111.

Barker H., Harrison B. D., 1978. Double infection, interference and superinfection in protoplasts exposed to two strains of raspberry ringspot virus. J. Gen. Virol., 40, 647-658.

Bergstrom G. C., Johnson M. C., Kuc J., 1982. Effects of local infection of cucumber by Colletotrichum lagenarium, Pseudomonas lachrymans, or tobacco necrosis virus on systemic resistance to cucumber mosaic virus. Phytopathology, 72, 922-926.

Bonnet Ph., Poupet A., Abad P., Venar P., Cardin L., 1986. Induction de nécrose foliaire, de protéines b et de résistance dans les interactions Tabac/Phytophthora. Agronomie, 6 (9), 829-837.

Burgess J., Motoyoshi F., Fleming E. N., 1974. Structural changes accompanying infection of tobacco protoplasts with two spherical viruses. Plant, 117, 133-144.

Burgyan J., Gaborjanyi R., 1984. Cross-protection and multiplication of mild and severe strains of TMV in tomato plants. Phytopathol. Z., 110 (2), 156-167.

Cassells A. C., Herrick C. C., 1977. Cross-protection between mild and severe strains of tabocco mosaic virus in doubly inoculated tomato plants. Virology, 78, 353-260.

Chadha K. C., MacNeill B. H., 1969. An antiviral principle from tomatoes systemically infected with tobacco mosaic virus. Can. J. Bot., 47, 513-518.

Chang L., Yang X., Tian B., 1982. Comparison of contents of viral double-stranded RNA in tobacco infected with ToMV and its avirulent mutani N14. Acta microbiol. sin., 22 (4), 327-332.

Channon A. G., Cheffins N. J., Hitchon G. H., Barker J., 1978. The effect of inoculation with an attenuated mutant strain of tobacco mosaic virus on the growth and yield of early glasshouse tomato crops. Ann. Appl. Biol., 88, 121-129.

Cheema S. S., Kapur S. P., Kaur H., 1983. Influence of citrus tristeza virus (CTV) and citrus exocortis viroid (CEV) infection, singly and in combination, on growth and metabolism of « Kagzi » lime (Citrus aurantifolia Swingle). Phytopathol. mediterr., 22 (3), 133-135.

Chessin M., 1983. Is there a plant interferon ? Botanic. rev., 49 (1), 1-28.

Costa A. S., Müller G. W., 1980. Tristeza control by cross protection: a U.S.-Brazil cooperative success. Plant Dis. Rep., 46 (6), 538-541.

Cox J. E., Fraser L. R., Broadbent J. P., 1976. Stem pitting of grapefruit : field protection by the use of mild strains, an evaluation of trials in two climatic districts. Proc. 7th Conf. Intl. Org. of Citrus Virologists.
Cress D. E., Kiefer M. C., Owens R. A., 1983. Construction of infectious potato spindle tuber viroid cDNA clones. N.A.R., 11, 6821-6835.

Davies J. W., Kaesberg P., 1974. Translation of virus in RNA : protein synthesis directed by several virus RNAs in cell-free extract from wheat germ. J. gen. Virol., 25, 11-20.

Dawson J. R. O., Motoyoshi F., Watts J. W., Bancroft J. B., 1975. Production of RNA and coat protein of a wild-type isolate and a temperature-sensitive mutant of cowpea chlorotic mottle virus in cowpea leaves and tobacco protoplasts. J. gen. Virol., 29, 99-107.

Devergne J. C., Cardin L., 1979. Phénomènes d'interférence entre souches du Virus de la Mosaïque du Concombre (CMV). I. - Répartition des antigènes viraux dans le Nicotiana tabacum var. Xanthi n.c., inoculé simultanément ou successivement par deux souches sérologiquement différentes. Ann. Phytopathol., 11 (3), 409-419.

De Zoeten G. A., Fulton R. W., 1975. Understanding generates possibilities. Phytopathology, 65, 221-222.

Dodds J. A., 1982. Cross-protection and interference between electrophoretically distinct strains of cucumber mosaic virus in tomato. Virology, 118 (1), 235-240.

Dodds J. A., Hamilton R. I., 1976. Structural interactions between viruses as a consequence of mixed virus infections. $A d v$. virus Res., 20, 33-86.

Dodds J. A., Lee Q. S., Tiffany M., 1985. Cross protection between strains of cucumber mosaic virus : effect of host and type of inoculum on accumulation of virions and double-stranded RNA of the challenge strain. Virology, 144, 301-309.

Douine L., Quiot J. B., Marchoux G., Clément M., 1979. Phénomènes d'interférence entre souches du CMV. II. - Effet de la température d'incubation sur la multiplication de deux souches du Virus de la Mosaïque du Concombre de sensibilités thermiques différentes, inoculées simultanément ou successivement à un hôte sensible : Nicotiana tabacum var. Xanthi n.c. Ann. phytopathol., 11 (3), 421-430.

Doz B., Delbos R., Dunez J., 1982. Prémunition : une compétition entre souches faibles et souches sévères pour une voie commune d'expression des symptômes. In : La sélection des plantes pour la résistance aux maladies. Coll. I.N.R.A., 11, 29-44.

Doz B., Jacquemond M., Marchoux G., Dunez J., 1983. Interaction entre souches de virus, application à la protection des plantes. In : Les antagonistes microbiens. Modes d'actions et application à la lutte biologique contre les maladies des plantes. Coll. I.N.R.A., 18, 59-70.

Fletcher J. T., Butler D., 1975. Strain changes in populations of tobacco mosaic virus from crops. Ann. appli. biol., 81, 409-412.

Fletcher J. T., Rowe J. M., 1975. Observations and experiments on the use of an avirulent mutant strain of tobacco mosaic virus as a means of controlling tomato mosaic. Ann. Appl. Biol., 81, 171-179.

Foglein F. L., Kalpagan C., Bates D. C., Premecz G., Nyitrai A., Farkas G. L., 1975. Viral RNA synthesis is renewed in protoplasts isolated from TMV-infected Xanthi tobacco leaves in an advanced stage of infection. Virology, 67, 74-79.

Fraser R. S. S., 1979. Systemic consequences of the local lesion reaction to tobacco mosaic virus in a tobacco variety lacking the $\mathbf{N}$ gene for hypersensitivity. Physiol. Plant Pathol., 14, 383-394.

Fraser R. S. S., 1982. Are pathogenesis-related proteins involved in acquired systemic resistance of tobacco plants to tobacco mosaic virus? J. Gen. Virol., 58, 305-313.

Fraser R. S. S., Clay C. M., 1983. Pathogenesis-related proteins and acquired systemic resistance : causal relationship or separate effects? Neth. J. Plant Pathol., 89, 283-292.

Fraser R. S. S., Loughlin S. A. R., Whenham R. J., 1979. Acquired systemic susceptibility to infection by tobacco mosaic virus in Nicotiana glutinosa. J. Gen. Virol., 43, 131-141.

Fulton R. W., 1951. Superinfection by strains of tobacco mosaic virus. Phytopathology, 41, 579-592.

Fulton R. W., 1975. Unilateral cross-protection among some NEPO viruses. Acta Hortic., 44, 29-31.

Fulton R. W., 1978. Superinfection by strains of tobacco streak virus. Virology, 85, 1-8. 
Gad-Edelbaum O. Sela I., Altman A., 1983. Polyinosinic-Polycytidylic acid in association with cyclic nucleotides activates the antiviral factor (AVF) in plant tissues. J. gen. Virol., 64 (1), 211-214.

Gera A., Loebenstein G., 1983. Further studies of a inhibitor of virus replication from tobacco mosaic virus-infected protoplasts of a local lesion-responding tobacco cultivar. Phytopathology, 73 (1), 111-115.

Gianinazzi S., 1983. Genetic and molecular aspects of resistance induced by infections or chemicals. Plant-Microbe Interaction. Ed. B. W. Nester and R. Kosuge I.

Gianinazzi S., Ahl P., Cornu A., Scalla R., 1980. First report of host b-protein appearance in response to a fungal infection in tobacco. Physiol. Plant Pathol., 16, 337-342.

Gianinazzi S., Kassanis B., 1974. Virus resistance induced in plants by polyacrylic acid. J. Gen. Virol., 23, 1-9.

Gianinazzi S., Pratt H. M., Shewry P. R., Miflin B. J., 1977. Partial purification and preliminary characterization of soluble leaf proteins specific to virus-infected tobacco plants. J. Gen. Virol., 34, 345-351.

Gianinazzi S., Vallée J. C., Martin C., 1969. Hypersensibilité aux virus température et protéines solubles chez le Nicotiana Xanthi n.c. C.R. Acad. Sci., Ser. D. Sci. nat., 268, 800-802.

Gilpatrick J. D., Weintraub M., 1952. An unusual type of protection with the carnation mosaic virus. Sciences, 115, 701-702.

Goto T., lizuka N., Komochi S., 1984. Selection and utilization of an attenuated isolate of pepper strain of tobacco mosaic virus (in Japanese). Ann. phytopathol. Soc. Jpn., 50 (2), 221-228.

Habili N., Francki R. I. B., 1974. Comparative studies on tomato aspermy and cucumber mosaic viruses. III. - Further studies on relationship and construction of a virus from parts of the two viral genomes. Virology, 61, 443-449.

Habili N., Kaper J. M., 1981. Cucumber mosaic virus-associated RNA-5. VII. - Double-stranded form accumulation and disease attenuation in tobacco. Virology, 112, 250-261.

Hamilton R. I., 1980. Defenses triggered by previous invaders : viruses. Plant Disease, vol. V. How Plants Defend Themselves. (Eds Horsfall J. G., Cowling E. B.), Academic Press. Inc. New York, 279301

Harrison B. D., Hanada K., 1976. Competitiveness between genotypes of raspberry ringspot virus is mannly determined by RNA 1. J. Gen. Virol., 31, 455-457.

Harrison B. D., Murant A. F., Mayo M. A., Roberts I. M., 1974. Distribution of determinants for symptom production, host range and nematode transmissibility between the two RNA components of raspberry ringspot virus. J. Gen. Virol., 22, 233-247.

Harrison B. D., Stefanac Z., Roberts I. M., 1970. Role of mitochondria in the formation of X-bordies in cells of Nicotiana clevelandii infected by tobacco rattle virus. J. Gen. Virol., 6 , 127-140.

Hatta T., Matthews R. E. F., 1976. Sites of coat protein accumulation in turnip yellow mosaic virus-intected cells. Virology. $73,1-16$.

Hecht E. 1., Bateman D. F., 1964. Non-specific acquired resistance to pathogens resulting from localized infection by Thielaviopsis basicola or viruses in tobacco leaves. Phytopathology, 54, 535-530.

Herson D., Schmidt A., Seal S., Marcus A., Van Vloten Doting L., 1979. Competitive mRNA translation in an in vitro system from wheat germ. J. biol. Chem., 254, 8245-8249.

Holling M., 1978. Some properties of a severe strain of tomato mosaic virus (TMV) isolated from a crop that had been inoculated with the mild strain MII-16. Annu. Rpt. Glasshouse Crops Res. Inst. (1977).

Honda Y., Matsui C., Otsuki Y., Takebe I., 1974. Ultrastructure of tobacco mesophyll protoplasts inoculated with cucumber mosaic virus. Phytopathol., 64, 30-34.

Jacquemond M., 1982. Phénomènes d'interférences entre les deux types d'ARN satellite du Virus de la Mosaique du Concombre. Protection des tomates vis-à-vis de la nécrose létale. C. R. Acad. Sci., Ser. 3., Paris, 294, 991-994.

Janet-Fritig B., 1986. Purification and characterization of 8 of the pathogenesis-related proteins in tobacco leaves reacting hypersensitively to tobacco mosaic virus. Plant Mol. Biol., 6, 69-80.
Janicka-Czarnecka I., Nienhaus F., 1981. Investigations on an extractable induced antiviral principle (AVF) in systemically diseased Phaseolus vulgaris upon tobacco mosaic virus infection. $Z$. Pflanzenkr. Pflanzenschutz, 88 (10), 577-583.

Jenns A. E., Caruso F. L., Kuc J., 1979. Non-specific resistance to pathogens induced systemically by local infection of cucumber with tobacco necrosis virus, Colletotrichum lagenarium or Pseudomonas lachrymans. Phytopathol. mediterr., 18, 129-134.

Jenns A. E., Kuc J., 1980. Characteristics of anthracnose resistance induced by localized infection of cucumber with tobacco necrosis virus. Physiol. Plant Pathol., 17, 81-91.

Jockusch H., 1968. Two mutants of tobacco mosaic virus temperature sensitive in two different functions. Virology, 35, 94101

Jones A. T., 1976. Serological specificity of isolates of cherry leaf roll virus from different natural hosts. Agric. Conspectus Sci., 39, 527532.

Kaper J. M., Toussignant M. E., 1977. Cucumber mosaic virusassociated RNA-5. I. - Role of host plant and helper strain in determining amount associated with virion. Virology, 80, 186-195.

Kassanis B., 1963. Interaction of viruses in plants. Adv. Virus Res., 10, 219-255.

Kassanis B., 1983. Has the plant a resistance system based on interferon-like proteins ? Phytopathol. Z., 108 (2), 185-190.

Kassanis B., White R. F., 1972. Interference between two satellite viruses of tobacco necrosis virus. J. Gen. Virol., 17, 177-183.

Kassanis B., Gianinazzi S., White R. F., 1974. A possible explanation of the resistance of virus-infected tobacco plants to second virus infection. J. Gen. Virol., 23, 11-16.

Kato S., Misawa T., 1976a. Isolation and identification of a substance interfering with local lesion formation produced in cowpea leaves locally infected with cucumber mosaic virus. Ann. phytopathol. Soc. Japan, 42, 450-455.

Kiho Y., Nishiguchi M., 1984. Unique nature of an attenuated strain of tobacco mosaic virus : autoregulation. Microbiol. Immunol., 28 (5), 589-599.

Kuc J., 1981. Multiple mechanisms, reactions rates, and induced resistance in plants. In : Plant Disease Control. R. C. Staples and G. H. Toenniessen, eds. John Wiley \& Sons, New York, 259-272.

Kunkel L. O., 1934. Studies on acquired immunity with tobacco and aucuba mosaic. Phytopathology, 24, 436-466.

Kuti J. O., Moline H. E., 1985. Effects of inoculation with a mild strain of tomato aspermy virus on the growth and yield of tomatoes and the potential for cross protection. Phytopathol. Z., 115, 56-60.

Lima J. A. A., Nelson M. R., 1975. Squash mosaic virus variability : nonreciprocal cross-protection between strains. Phytopathology, 65, 837-840.

Loebenstein G., 1972. Localization and induced resistance in virusinfected plants. Annu. Rev. Phytopathol., 10, 177-206.

Loebenstein G., Gera A., 1981. Inhibitor of virus replication released from tobacco mosaic virus-infected protoplasts of a local lesionsresponding tobacco cultivar. Virology, 114 (1), 132-139.

Loebenstein G., Ross A. F., 1963. An extractable agent, induced in uninfected tissues by localized virus infections, that interferes with infections by tobacco mosaic virus. Virology, 20, 507-517.

Loebenstein G., Cohen J., Shabtai S., Coutts R. H. A., Wood K. R., 1977. Distribution of cucumber mosaic virus in systemically infected tobacco leaves. Virology, 81, 117-125.

Mandryk M., 1963. Acquired systemic resistance to tobacco mosaic virus in Nicotiana tabacum evoked by stem infection with Peronospora tabacina Adam. Aust. J. Agric. Res., 14, 315-318.

McKinney H. H., 1929. Mosaic diseases in the Canary Islands, West Africa and Gibraltar. J. agric. Res., 39, 557-578.

McIntyre J. L., Dodds J. A., Hare J. D., 1981. Effects of localized infections of Nicotiana tabacum by tobacco mosaic virus against diverse pathogens and an insect. Phytopathology, 71, 297-301.

Marchoux G., Douine L., Devergne J. C., 1975. Cucumovirus : studies on construction of pseudo-recombinants from parts of their RNA genomes. Comm. $3^{\text {rd }}$ Int. Congress for Virology. MADRID 90.

Marchoux G., Douine L., Quiot J. B., 1976. Comportement thermique différentiel de certaines souches du virus de la Mosaïque du Concombre. Hypothèse d'un mécanisme pléiotropique reliant plusieurs propriétés. C. R. Acad. Sci., Ser. D, 283, 1601-1604. 
Marrou J., Migliori A., 1971. Essai de protection des cultures de tomates contre le virus de la Mosaïque du Tabac : mise en évidence d'une spécificité étroite de la prémunition entre souches et ce virus. Ann. Phytopathol., 3, 447-459.

Marrou J., Migliori A., 1972. La prémunition, une nouvelle méthode de protection des cultures contre le virus de la Mosaïque du Tabac. Pépiniéristes Hortic. Maraîchers, 124, 27-31.

Mozes R., Antignus Y., Sela I., Harpaz I., 1978. The chemical nature of an antiviral factor (AVF) from virus-infected plants. J. Gen. Virol., 38, 241-249.

Murakishi H., Carlson P., 1976. Regeneration of virus-free plants from dark-green islands of tobacco mosaic virus-infected tobacco leaves. Phytopathology, 66, 931-932.

Navatel J. C., Trapateau M., Marchoux G., 1983. La prémunition : méthode de protection contre les virus. Bilan de la lutte contre la mosaïque du Tabac. Perspectives. C. R. Col. ACTA, Faune et Flore auxiliaires en Agriculture, mai 1983, 36-42.

Niblett C. L., Dickson E., Fernow K. H., Horst R. K., Zaitlin M., 1979. Cross protection among four viroids. Virology, 91, 198-203.

Novikov V. K., Atabekov, 1970. A study of the mechanisms controlling the host range of plant viruses. I. Specific receptors of Chenopodium amaranticolor. Virology, 41, $101-107$.

Otsuki Y., Takebe I., 1978. Production of mixedly coated particles in tobacco mesophyll protoplasts doubly infected by strains of tobacco mosaic virus. Virology, 84, 162-171.

Rast A. Th. B., 1972. MII-16, an artificial symptomless mutant of tobacco mosaic virus for seedling inoculation of tomato crops. Neth. J. Plant Pathol., 78, 110-112.

Rast A. Th. B., 1975. Variability of tobacco mosaic virus in relation to control of tomato mosaic in glasshouse tomato crops by resistance breeding and cross protection. Agric. Res. Rep. 834 Pudoc, Wageningen, p. 76.

Rast A. Th. B., 1979. Infection of tomato seed by different strains of tobacco mosaic virus with particular reference to the symptomless mutant M11-16. Neth. J. Plant Pathol., 85, 223-333.

Reichman M., Devash Y., Suhadolnik R. J., Sela I., 1983. Human leukocyte interferon and the antiviral factor (AVF) from virusinfected plants stimulate plant tissues to produce nucleotides with antiviral activity. Virology, 128 (1), 240-244.

Richards K. E., Jonard G., Jacquemond M., Lot H., 1978. Nucleotide sequence of cucumber mosaic virus associated RNA5. Virology, 89, 395-408.

Reid M. S., Matthews R. E. F., 1966. On the origin of mosaic induced by turnip yellow mosaic virus. Virology, 28, 563-570.

Roberts D. A., 1983. Acquired resistance to tobacco mosaic virus transmitted to the progeny of hypersensitive tobacco. Virology, 124 (1), 161-163.

Robertson H. D., Webster R. E., Zinder N. D., 1986. Bacteriophage coat protein as repressor. Nature 5141, 533-536.

Robinson D. J., 1977. A variant of tobacco rattle virus : evidence for a second gene in RNA-2. J. Gen. Virol., 35, 37-43.

Ross A. F., 1961 a. Localized acquired resistance to plant virus infection in hypersensitive hosts. Virology, 14, 329-339.

Ross A. F., $1961 b$. Systemic acquired resistance induced by localized virus-infections in plants. Virology, 14, 340-358.

Ross A. F., 1974. Interactions of viruses in the host. In Virus Diseases of Ornamental Plants (R. H. Lawson and M. K. Corbett, eds.) Int. Soc. Hortic. Sci. The Hague. Netherlands, 247-260.

Sakai F., Dawson J. R. O., Watts J. W., 1983. Interference in infections of tobacco protoplasts with two bromoviruses. J. Gen. Virol., 64 (6), 1347-1354.
Salaman R. N., 1933. Protective inoculation against a plant virus. Nature (London), 131, 468.

Salomon R., Bar-Joseph M., 1982. Translational competition between related virus RNA species in cell-free systems. J. Gen. Virol., 62 (2), 343-347.

Sanger H. L., 1968. Characteristics of tobacco rattle virus. I. Evidence that its two particles are functionally defective and mutually complementing. Mol. gen. Genet., 101, 346-347.

Schuster G., Wertzler C., 1982. On virus-induced virus inhibitors from locally TMV-infected plants of Nicotiana glutinosa L. Phytopathol. Z., 104 (1), 46-59.

Sela 1., Applebaum S. W.. 1962. Occurrence of an antiviral factor in virus-infected plants. Vtrology, 17, 543-548.

Sela I., Hauschner A., Mozes R., 1978. The mechanism of stimula tion of the antiviral factor (AVF) in Nicotiana leaves: the involvement of phosphorylation and the role of the $\mathrm{N}$-gene. Virology, 89, 16.

Sela I., 1981. Plant-virus interactions related to resistance and localization of viral infection. Adv. Virus Res., 26, 201-237.

Shalla T. A., Petersen L. J., 1978. Studies on the mechanism of viral cross protection. Phytopathology, 68, 1681-1683.

Sherwood J. L., Fulton R. W., 1982. The specific involvement of coat protein in tobacco mosaic virus cross protection. Virology, 119, 150-158.

Shih D. S., Kaesberg P., 1976. Translation of the RNAs of brome mosaic virus of the monocistronic nature : $\mathrm{RNA}_{1}$ and $\mathrm{RNA}_{2} . J . \mathrm{mol}$. Biol., 103, 77-88.

Siegel A., 1959. Mutual exclusion of strains of tobacco mosaic virus. Virology, 8, 470-477.

Thung T. H., 1931. Smetstof en plantencel bij enkele virusziekten van de tabaksplant. Handet. Nederl.-Ind. Natuurwetensch. Congr. 6de 1931, pp. 450-463; abstr. in Rev. appl. Mycol., 11, 750-751 (1932).

Tomlinson J. A., Shepherd R. J., 1978. Studies on mutagenesis and cross protection of cauliflower mosaic virus. Ann. appl. Biol., 90, $223-231$

Travers A., 1984. Regulation by anti-sense RNA, Nature, 311, 410.

Van Loon L. C., 1976. Specific soluble leaf proteins in virusinfected tobacco plants are not normal constituents. J. Gen. Virol., 30, 375-379.

Van Loon L. C., 1983. Proceedings of the workshop on pathogenesisrelated (b) proteins in plants. 1983. Neth. J. Plant Pathol., 89, 239325 .

Van Tol R. G. L., Van Vloten-Doting L., 1979. Translation of alfalfa mosaic virus RNA $_{1}$ in mRNA-dependent translation system from rabbit reticulocyte lysates. Eur. J. Biochem., 9, 461-468.

Wolanski B. S., Chambers T. C., 1971. The multiplication of lettuce necrotic yellow virus. Virology, 44, 582-591.

Wu J. H., Rappaport I., 1961. An analysis of the interference between two strains of tobacco mosaic virus on Phaseolus vulgaris. Virology, 14, 259-263.

Yarwood C. E., 1960. Localized acquired resistance to tobacco mosaic virus. Phytopathology, 50, 741-744.

Yeh S. D., Gonsalves G., 1984. Evaluation of induced mutants of papaya ringspot virus for control by cross protection. Phytopatho$\log y, 74$ (9), 1086-1091.

Zaitlin M., 1976. Viral cross-protection : more understanding is needed. Phytopathology, 66, 382-383.

Ziemiecki A., Wood K. R., 1976. Proteins synthesized by cucumber cotyledons infected with two strains of cucumber mosaix virus. $J$. Gen. Virol., 31, 373-381. 